\title{
KETIDAKEFEKTIFAN KALIMAT PADA SURAT DINAS PEMERINTAH : STUDI KASUS KABUPATEN GORONTALO
}

\author{
Darmawati M.R. \\ Kantor Bahasa Gorontalo \\ Jalan dr. Zainal umar Sidiki, Tunggulo, Tilongkabila \\ Kabupaten Bone Bolango, Gorontalo, Indonesia \\ Pos-el: darmawatimajid@gmail.com
}

\begin{abstract}
Abstrak
Surat merupakan alat komunikasi resmi antarlembaga pemerintah yang wajib menggunakan bahasa Indonesia yang efektif. Hal itu berarti bahwa bahasa Indonesia yang digunakan dalam tata naskah dinas adalah bahasa Indonesia yang baik dan benar. Namun, apakah yang dijadikan alat ukur atau kriteria bahasa yang baik? Apa alat ukur dan kriteria bahasa yang benar? Tulisan ini bertujuan menguraikan ketidakefektifan kalimat pada surat dinas pemerintah Kabupaten Gorontalo, dan mendeskripsikan faktor penyebab ketidakefektifannya. Metode pengumpulan data tulisan ini adalah studi pustaka dengan teknik catat. Analisis data menggunakaan analisis deskriptif dengan berdasar pada teori Kalimat Efektif. Dari temuan yang diperoleh tampak bahwa kalimat-kalimat yang benar secara struktur bahasanya, belum tentu sudah efektif kalimatnya, apalagi jika memang sudah kacau dari segi struktur. Dari 25 data yang dianalisis pada tulisan ini, masih terdapat banyak kesalahan yang menyebabkan kalimat-kalimat dalam surat dinas tidak efektif. Bahkan, tampak beberapa kesalahan berulang seperti penggunaan tanda titik dua setelah kata pada, kekeliruan penulisan preposisi di dan awalan di- , kontaminasi bentuk aktif dan pasif, penulisan singkatan sampai dengan yang keliru, penghilangan salah satu unsur utama kalimat, baik subjek maupun objek, dan penggunaan partikel-nya yang tidak tepat pada penutup surat. Dari ke-25 data tersebut, faktor-faktor penyebab ketidakefektifan kalimat dalam bahasa surat di Lingkungan Pemerintah Kabupaten Gorontalo, yakni kontaminasi atau kerancuan, pleonasme, ambiguitas, ketidakjelasan subjek, kemubaziran preposisi dan kata, kesalahan nalar, ketidaktepatan bentuk kata, ketidaktepatan makna kata, pengaruh bahasa daerah, dan pengaruh bahasa asing.
\end{abstract}

Katakunci: ketidakefektifan, kalimat efektif, srat dinas pemerintah

\section{The Ineffectiveness Sentence at the Official Service Letters Case Study at Gorontalo District Government}

\begin{abstract}
Letters are official communication tools between government institutions that are required to use effective Indonesian. That means that the Indonesian language used in official document manuscripts is Indonesian that is good and right. However, what is good measurement tools or language criteria? What are the correct measuring tools and language criteria? This paper aims to describe the ineffectiveness of the sentence on the Gorontalo District government official service letter and find out the factors causing its ineffectiveness. The method used in this paper was a literary study. Data were analyzed by descriptive analysis based on Effective Sentence theory. From the findings obtained that the sentences that are structurally correct, may not necessarily have been effective sentences, especially if they have been confused in terms of structure. Of the 25 data analyzed in this paper, there are still many errors that cause the sentences in the service letter to be ineffective. In fact, it appears several repetitive errors such as the use of a colon after the word in, the error of writing the preposition di- and the prefix contaminated active and passive forms, abbreviation of sampai dengan is written wrong, omitting one of the main elements of the sentence, both the subject and object and the use -nya particles are not right on the cover of the letter. From the 25 data, the factors causing ineffectiveness of sentences in letter language in Gorontalo District Government Environment, namely contamination or ambiguity, pleonasm, ambiguity, subject obscurity, waste of prepositions and words, erroneous reasoning, inaccurate word form, inaccurate meaning of words, the influence of regional languages, and the influence of foreign languages.
\end{abstract}

Keywords: inaffective, effective sentences, official texts letters

\section{PENDAHULUAN}

Cara seseorang mempersepsi realitas berawal dari struktur (susunan) bahasanya. Hal ini yang mendasari gagasan Benyamin Lee Whorf (Whorf, 1964), bersama Sapir dalam mengajukan tesisnya tentang relativitas linguistik yang dikenal dengan nama "hipotesis
Sapir-Whorf", hal yang menjadi perdebatan banyak ahli bahasa di kemudian hari.

Bahasa akhirnya menjadi satu-satunya kajian yang hampir seumur dengan manusia itu sendiri. Bahasa, yang dperkirakan sama tuanya dengan manusia tersebut telah banyak dikaji untuk mengeksplorasi keunikannya, dari permasalahan bentuk dan strukturnya, penggunaannya, bahkan sampai pada 
bagaimana bahasa dapat memengaruhi cara berpikir manusia serta membentuk kebudayaan mereka. Bahkan, Harari (Harari, 2019) dalam buku larisnya, Sapiens: Sejarah Singkat Umat Manusia mengungkap bahwa spesies manusia mampu bertahan hidup setelah ratusan tahun justru karena kemampuannya menggunakan bahasa.

Terlepas dari semua bahasan mengenai bahasa, sebenarnya, persoalan yang muncul, mengerucut pada satu hal, yaitu bagaimana bahasa berperan sebagai alat komunikasi sehingga manusia mampu bertahan hidup dan mempertahankan keturunannya.

Dalam berkomunikasi, manusia menggunakan bahasa dalam bentuk lisan dan tertulis. Dalam komunikasi lisan, kaidah bahasa boleh diabaikan selama kedua belah pihak (penutur dan lawan tutur) saling mengerti. Akan tetapi, dalam komunikasi tertulis, tidak demikian. Bahasa dalam komunikasi tertulis apalagi di ragam formal antarlembaga pemerintah, harus menaati aturan yang berlaku. Di Indonesia, aturan itu tertuang dalam UU Nomor 24 Tahun 2009 tentang Bendera, Bahasa, dan Lambang Negara serta Lagu Kebangsaan, Pasal 34. (Pemerintah Indonesia, 2009).

Jika demikian adanya, bahasa menjadi bukan sekadar alat komunikasi melainkan alat pikir dan alat ekspresi. Sebagai alat berpikir dan berekspresi bahasa bersistem dan perlu menaati kaidah bahasa yang berlaku.

Surat merupakan salah satu sarana untuk berkomunikasi tertulis. Sifatnya dapat resmi maupun formal, rahasia atau umum. Surat dinas adalah salah satu jenis surat resmi yang mengandung informasi tertentu yang dapat berupa perintah, pemberitahuan, imbauan, tugas, permintaan, teguran dan lainlain. Oleh karena itu, surat selayaknya ditulis menggunakan bahasa yang efektif. Efektif dalam hal ini berarti surat yang ditulis menggunakan bahasa Indonesia yang baik, dan benar.

Mengapa bahasa dalam surat dinas perlu mengikuti kaidah bahasa yang berlaku? Hal tersebut dikarenakan penggunaan bahasa dalam surat telah diatur dalam Peraturan Kepala Arsip Negara Republik Indonesia Nomor 2 tentang Pedoman Tata Naskah Dinas, Bab II, Bagian A, No. 3, bahwa naskah dinas harus menggunakan bahasa Indonesia yang formal, logis secara efektif, singkat, padat, dan lengkap serta mudah dipahami bagi pihak penerima naskah dinas. (Kepala Arsip Nasional Republik Indonesia, 2014).

Bahasa Indonesia yang efektif berarti bahasa Indonesia yang digunakan dalam tata naskah dinas adalah bahasa Indonesia yang baik dan benar. Namun, apakah yang dijadikan alat ukur atau kriteria bahasa yang baik? Apa alat ukur dan kriteria bahasa yang benar?

Bahasa Indonesia yang baik dan benar dapat dilihat setidaknya dari tiga hal, yaitu struktur, diksi, maupun ejaannya. Penggunaan bahasa dalam surat memerlukan kecermatan dan ketepatan baik di dalam penerapan kaidah ejaan, struktur, bentuk kata dan pemilihannya serta unsur bahasa dalam struktur kalimat.

Jelas bahwa aturan yang mengatur penggunaan bahasa dalam surat sebagai tata naskah dinas sudah ada. Akan tetapi aturan itu belum maksimal diterapkan.

Fenomena yang terjadi adalah unsur kecermatan dan ketepatan bahasa dalam surat sering kali dikesampingkan bahkan disepelekan. Banyak surat yang beredar tidak menggunakan ejaan dengan baik, kalimat yang tidak mengandung pesan apa-apa, kalimat yang tidak selesai, kalimat-kalimat bernada feodal, dan sebagainya.

Tulisan mengenai kalimat efektif dalam surat dinas pernah dilakukan oleh Ahmad Dedi Mutiadi, dkk. Tulisan mereka berjudul Ketidakefektifan Kalimat pada Surat Dinas Tingkat Desa Kecamatan Darma Kabupaten Kuningan dan Ancangan Pola Pembinaannya (Mutiadi, dkk, 2018). Penelitian tersebut bertujuan mengetahui ketidakefektifan kalimat pada surat dinas yang dibuat oleh staf administrasi desa yang berada di lingkungan Kecamatan Darma serta menghasilkan ancangan pola pembinaan bahasa Indonesia berdasarkan analisis kesalahan kalimat pada surat dinas. Temuan penelitian itu adalah : (1) 
banyak surat yang menggunakan kalimat yang tidak efektif. Misalnya, kalimatnya terlalu panjang, banyak menggunakan kata-kata yang tidak diperlukan, dan ketidakjelasan subjek dan predikat, (2) ancangan pola pembinaan bahasa dalam bentuk rancangan pelaksaan pembinaan bahasa. Materi yang akan dibinakan adalah pilihan kata, penggunaan kalimat, dan sistematika penulisan. Selain tulisan Mutiadi, dkk. tersebut, ada pula tulisan Adiyasa, dkk yang berjudul Penggunaan Bahasa Indonesia dalam Surat Dinas di Kantor Perbekel Desa Penglumbaran dan Implikasinya pada Pembelajaran Menulis (Adiyasa, 2018). Penelitian tersebut bertujuan mendeskripsikan (1) kesalahan penggunaaan ejaan pada surat dinas yang disusun pegawai kantor Perbekel Desa Penglumbaran, (2) kesalahan penggunaan pilihan kata pada surat dinas yang disusun pegawai kantor Perbekel Desa Penglumbaran, dan (3) implikasi penggunaan bahasa Indonesia terhadap pembelajaran menulis surat di sekolah. Dari hasil penelitian tersebut ditemukan (1) kesalahan terbanyak ditemukan pada penggunaan ejaan 479 kesalahan. (2) kesalahan pemilihan kata sebanyak 53 kesalahan. (3) implikasi penelitian ini dibedakan menjadi dua yaitu implikasi teoretis dan implikasi praktis.

Tulisan mengenai Kalimat Efektif juga telah dilakukan salah satunya oleh Ramadhanti, dalam media yang berbeda yaitu karya tulis ilmiah, dengan judul "Penggunaan Kalimat Efektif dalam Karya Ilmiah Siswa: Aplikasi Semantik Studi Kasus Siswa Kelas XI SMK Negeri 2 Lembah Gumanti” (Ramadhanti, 2015). Penelitian tersebut adalah aplikasi semantik dalam pembelajaran bahasa Indonesia terutama dalam penggunaan kalimat efektif. Kalimat tidak efektif, ambigu, redundansi dan ambiguitas dapat mempengaruhi efektivitas. Penelitian ini dalam bentuk kata-kata, frase, dan kalimat itu penanda kalimat efektif yang diuraikan dalam pendapat Nasucha. Kalimat efektif melihat dalam komunikasi lisan dan komunikasi tertulis. Kalimat efektif sangat memengaruhi pembentukan komunikasi antara pembicara dan pendengar. Kalimat tidak efektif dalam karya ilmiah siswa masih ditemukan. Itu mempengaruhi pemahaman siswa menulis. Selain itu, adapula tulisan Asri mengenai "Analisis Kesalahan Diksi dan Kalimat pada Surat Dinas di Kantor Wali Kota Makassar. (B., 2014)."

Belum ada tulisan yang membahas faktorfaktor penyebab ketidakefektifan kalimat dengan gamblang dari keempat tulisan tersebut. Untuk itulah, tulisan ini hadir mengisi kekurangan kajian mengenai ketidakefektifan kalimat terutama faktor-faktor yang menyebabkan ketidakefektifan kalimat tersebut. Meskipun penelitian dan kajian mengenai analisis kesalahan berbahasa dan ketidakefektifan kalimat dalam surat dinas ini telah banyak dilakukan, kesalahan-kesalahan tersebut tetap berlanjut dan terus menerus dilakukan. Oleh karena itu, penelitian dan kajian serupa tetap perlu dilakukan dan ditulis sambil mencari cara efektif dan efisien untuk menyosialisasikan temuan-temuan penelitian sebelumnya. Semakin banyak penelitian dan kajian akan memperkaya referensi mengenai berbagai kesalahan penggunaan bahasa Indonesia.

Tulisan ini bertujuan menguraikan ketidakefektifan kalimat pada surat dinas pemerintah Kabupaten Gorontalo dan mengetahui faktor penyebab ketidakefektifan itu. Manfaat tulisan ini dimaksudkan sebagai bahan pertimbangan bagi staf pemerintah Kabupaten Gorontalo dan pemerintah daerah lain dalam menulis surat dengan bahasa Indonesia yang baik dan benar., dengan harapan bahwa surat-surat dinas pemerintah akan lebih tertata bahasanya.

\section{TEORI}

\section{Surat Dinas}

Surat merupakan informasi tertulis sebagai alat komunikasi yang dibuat dengan persyaratan. Bratawidjaja memberi pengertian lebih lengkap, yaitu surat sebagai sarana menyampaikan pernyataan atau informasi yang dapat berupa pemberitahuan, pernyataan, permintaan, laporan, pemikiran, dan 
sangggahan. Informasi yang lengkap dalam surat diperlukan untuk mencegah terjadinya salah paham (Bratawidjaja, 1988).

Bratawidjaja juga memaparkan fungsi surat dinas sebagai berikut.

1. Surat berfungsi sebagai utusan atau wakil penulis/instansi pengirimnya.

2. Surat berfungsi sebagai bukti tertulis, misalnya surat perjanjian.

3. Surat berfungsi sebagai alat pengikat karena dapat diarsipkan dan dilihat kembali bila diperlukan Surat berfungsi sebagai bukti sejarah

4. Surat berfungsi sebagai pedoman kerja

5. Surat berfungsi sebagai jaminan keamanan.

\section{Aturan mengenai Surat sebagai Tata Naskah Dinas}

Pada Pasal 33 UU Nomor 24 Tahun 2009 tentang Bendera, Bahasa, dan Lambang Negara, serta Lagu Kebangsaan tercantum

(1) Bahasa Indonesia wajib digunakan dalam komunikasi resmi di lingkungan kerja pemerintah dan swasta.

(2) Pegawai di lingkungan kerja lembaga pemerintah dan swasta sebagaimana dimaksud pada ayat (1) yang belum mampu berbahasa Indonesia wajib mengikuti atau diikutsertakan dalam pembelajaran untuk meraih kemampuan berbahasa Indonesia.

Pasal ini jelas mengatur kewajiban menggunakan bahasa Indonesia dalam komunikasi resmi. Kewajiban itu terkait dengan fungsi dan kedudukan bahasa Indonesia sebagai bahasa negara. Sebagai bahasa negara, bahasa Indonesia berfungsi sebagai (1) bahasa resmi kenegaraan, (2) bahasa pengantar resmi di lembaga-lembaga pendidikan, (3) bahasa resmi di dalam perhubungan pada tingkat nasional untuk kepentingan perencanaan dan pelaksanaan pembangunan serta pemerintahan, dan (4) bahasa resmi dalam pengembangan kebudayaan dan pemanfaatan ilmu pengetahuan serta teknologi modern. (Sugono, 2009).
Sebelum Peraturan Kepala Arsip Republik Indonesia Tahun 2014 tentang Pedoman Tata Naskah Dinas ditetapkan, sebelumnya telah ada Peraturan Menteri Pendayagunaan Aparatur Negara dan Reformasi Birokrasi Nomor 80 tahun 2012 tentang Pedoman Tata Naskah Dinas Intansi Pemerintah.

Tata Naskah Dinas adalah pengaturan tentang jenis, format, penyiapan, pengamanan, pengabsahan, distribusi dan media yang digunakan dalam komunikasi kedinasan. (Kepala Arsip Nasional Republik Indonesia, 2014). Naskah Dinas itu adalah informasi tertulis sebagai alat komunikasi kedinasan yang dibuat oleh pejabat yang berwenang di lingkungan lembaga negara, pemerintahan daerah, perguruan tinggi negeri, BUMN/BUMD dalam rangka penyelenggaraan tugas pemerintahan dan pembangunan.

Dalam Perka ANRI Nomor 2 Tahun 2014 juga diatur mengenai jenis-jenis naskah dinas sebagai berikut.

1. Naskah Dinas Arahan

a. Naskah dinas pengaturan: 1) peraturan, 2) pedoman, 3) Petunjuk pelaksanaan/petunjuk teknis, 4) instruksi, 5) Standar Operasional Prosedur (SOP), dan 6) surat edaran.

b. Naskah dinas penetapan (keputusan); dan

c. Naskah dinas penugasan (surat perintah/ surat tugas).

2. Naskah Dinas Korespondensi

a. Naskah dinas korespondensi intern: 1) nota dinas; dan 2) disposisi.

b. Naskah dinas korespondensi ekstern.

3. Naskah Dinas Khusus

a. surat perjanjian: 1) Perjanjian dalam negeri; dan 2) Perjanjian internasional.

b. surat kuasa;

c. berita acara;

d. surat keterangan;

e. surat pengantar; dan

f. pengumuman.

4. Laporan

5. Telaah staf

Selanjutnya dalam latar belakang terbitnya Permenpan Nomor 80 Tahun 2012 Pedoman 
Tata Naskah Dinas Intansi Pemerintah dijelaskan bahwa:

"Tata naskah dinas sebagai salah satu unsur administrasi umum meliputi, antara lain, pengaturan tentang jenis dan penyusunan naskah dinas, penggunaan lambang negara, logo dan cap dinas, penggunaan bahasa Indonesia yang baik dan benar, pengurusan naskah dinas korespondensi, kewenangan, perubahan, pencabutan, pembatalan produk hukum, dan ralat. "

Penggunaan bahasa Indonesia yang baik dan benar yang dimaksud dalam permen tersebut meliputi bahasa Indonesia yang baik dan benar, baik struktur, diksi, maupun ejaannya. Salah satu asas Pedoman Tata Naskah Dinas Instansi Pemerintah sebagaimana diatur dalam permen tersebut adalah efektif dan efisien. Efektif dan efisien yang dimaksud adalah dalam penulisan, penggunaan ruang atau lembar naskah dinas, spesifikasi informasi, serta dalam penggunaan bahasa Indonesia yang baik, benar, dan lugas.

\section{Kriteria Bahasa Indonesia yang Baik dan Benar}

Kriteria yang digunakan untuk melihat penggunaan bahasa yang benar adalah kaidah bahasa (Sugono, 2009). Sugono menguraikan lebih lanjut bahwa kaidah bahasa itu terdiri atas:

1. tata bunyi (fonologi),

2. tata bahasa (kata dan kalimat),

3. kosakata (termasuk istilah),

4. ejaan, dan

5. makna.

Misalnya pada aspek tata bunyi, dikenal bunyi /f/, /v/, dan /z/, sehingga kata yang tepat adalah, fakir bukan pakir, zakat bukan jakat, vitamin bukan pitamin, dan aktif bukan aktip.

Pada aspek tata bahasa misalnya, yang benar adalah mengubah bukan merubah/merobah, mengebut bukan ngebut, tegakkan bukan tegakan, pertanggungjawaban bukan pertanggungan jawab.
Pada segi kalimat, ada kalimat yang tidak memiliki subjek sehingga struturnya tidak tepat. Seperti pada kalimat berikut.

Pada tabel di atas memperlihatkan bahwa siswa laki-laki lebih sedikit dari pada siswa perempuan.

Pada segi kosakata dan istilah, ada katakata seperti dampak (impact), bandar udara, keluaran (output), dan pajak tanah (land tax) dipilih sebagai istilah yang tepat daripada pengaruh, pelabuhan udara, hasil, dan pajak bumi.

Pada aspek ejaan, kata yang tepat adalah ramadan bukan ramadhan, azan bukan adzan dan, magrib bukan maghrib, dikarenakan dalam bahasa Indonesia, konsonan rangkap $d h$, $d z$, dan $g h$ belum diserap. Demikian halnya penulisan analisis bukan analisa, nasihat bukan nasehat, objek bukan obyek, jomlo bukan jomblo.

Sementara itu dari segi makna, penggunaan bahasa Indonesia yang benar berkaitan dengan penggunaan kata yang sesuai dengan tuntutan makna, misalnya tidak menggunakan kata yang bermakna konotatif dalam bahasa ilmu.

Jadi, penggunaan bahasa yang benar adalah penggunaan bahasa sesuai dengan kaidah bahasa. Penggunaan bahasa yang baik adalah ketepatan memilih ragam bahasa yang sesuai dengan kebutuhan komunikasi (Sugono, 2009). Pemilihan ragam bahasa itu bertalian dengan topik yang dibicarakan, tujuan pembicaraan, orang yang diajak berbicara (komunikasi lisan), atau pembaca (komunikasi tertulis), dan tempat pembicaraan. Bahasa yang baik juga bernalar, logis sesuai dengan tata nilai yang berlaku di masyarakat.

\section{Kalimat Efektif}

Kalimat efektif adalah kalimat yang baik karena apa yang dipikirkan atau dirasakan oleh si pembicara (penulis dalam bahasa tulis) dapat diterima dan dipahami oleh pendengar (pembaca dalam basa tulis) sama benar dengan apa yang dipikirkan atau dirasakan oleh si penutur atau penulis (Badudu, 1995). Sementara itu, menurut Putrayasa, kalimat efektif mampu membuat proses penyampaian 
dan penerimaan pesan berlangsung dengan sempurna (Putrayasa, 2014). Lebih lanjut, Putarayasa menjelaskan bahwa kalimat efektif mampu membuat isi atau maksud yang disampaikan si pembicara tergambar dalam pikiran si penerima) pembaca/pendengar) persis seperti apa yang disampaikannya. Hal tersebut terjadi jika kata-kata yang mengandung kalimat itu sanggup mengungkapkan kandungan gagasan, ditinjau dari segi diksi, struktur, dan logikanya. Kalimat efektif harus berterima secara tata bahasa dan makna, dan mencapai sasarannya dengan baik sebagai alat komunikasi.

Ada dua syarat yang harus dipenuhi untuk menyusun kalimat efektif, yaitu: syarat awal utama (meliputi pemilihan kata atau diksi dan penggunaan pedoman ejaan) dan syarat awal kedua (meliputi penulisan huruf, penulisan kata, dan tanda baca). Putrayasa juga kemudian memaparkan struktur dan ciri kalimat efektif (Putrayasa, 2014). Struktur kalimat efektif terdiri atas:

1. struktur kalimat umum,

2. struktur kalimat pararel, dan

3. struktur kalimat periodik.

Sementara itu, ciri kalimat efektif adalah

1. kesatuan (unity),

2. kehematan (economy),

3. penekanan (emphasis), dan

4. kevariasian (variety).

Masih menurut Putrayasa, di samping harus memenuhi persyaratan diksi dan struktur yang baik, kalimat efektif harus memiliki daya nalar yang baik (Putrayasa, 2014). Penalaran itu dapat dilihat sejauh mana suatu kalimat mengganggu pikiran pembaca atau pendengarnya. Misalkan pada kalimat berikut.

Saya mengajar Matematika.

Sekilas memang tidak ada yang salah dengan kalimat tersebut. Akan tetapi, jika dibaca berulang-berulang dan diresapi artinya akan timbul kerancuan. Apakah Matematika dapat diajar? Kalimat tersebut bisa benar jika tertulis sebagai berikut.

Saya mengajarkan Matematika.

Kalimat dapat dilihat dari beberapa segi. Dari segi fungsinya, kalimat adalah alat komunikasi. Dilihat dari segi bentuk dan proses terjadinya, kalimat membentuk suatu struktur atau pola yang terdiri atas unsur-unsur yang teratur. Dari contoh tersebut kita dapat menyimpulkan bahwa kalimat yang menurut tata bahasa dan betul struktur dan polanya belum tentu efektif. Sehingga kalimat efektif dapat diformulasikan sebagai kalimat yang baik dan benar baik dilihat dari segi diksi, struktur, maupun logika.

\section{Faktor-Faktor Penyebab Ketidakefektifan Kalimat}

Ada beberapa faktor yang menyebabkan ketidakefektifan kalimat (Putrayasa, 2014), yaitu:

1) kontaminasi atau kerancuan,

2) pleonasme,

3) ambiguitas,

4) ketidakjelasan subjek,

5) kemubaziran preposisi dan kata,

6) kesalahan nalar,

7) ketidaktepatan bentuk kata,

8) ketidaktepatan makna kata,

9) pengaruh bahasa daerah, dan

10) pengaruh bahasa asing.

\section{Kontaminasi}

Kontaminasi adalah suatu gejala bahasa yang dalam bahasa Indonesia disebut dengan kerancuan. Kalimat yang rancu adalah kalimat yang susunannya tidak teratur sehingga informasinya sulit dipahami. Badudu (J.S. Badudu, 1993) membedakan kontaminasi itu menjadi:

1) kontaminasi kalimat,

2) kontaminasi susunan kata, dan

3) kontaminasi bentukan kata.

\section{Pleonasme}

Pleonasme adalah pemakaian kata-kata yang berlebihan. Badudu memaparkan bahwa gejala pleonasme ini timbul karena beberapa kemungkinan, antara lain (J.S. Badudu, 1993):

1) pembicara tidak sadar bahwa yang diucapkannya itu mengandung sifat berlebih-lebihan. Jadi, dibuat dengan tidak sengaja,

2) dibuat bukan dengan tidak sengaja, melainkan karena pembaca tidak tahu bahwa kata-kata yang diucapkannya 
mengungkap pengertian yang berlebihlebihan, dan

3) dibuat dengan sengaja sebagai salah satu bentuk gaya bahasa, untuk memberikan tekanan pada arti (intensitas).

\section{Ambiguitas}

Ambiguitas diartikan sebagai tafsiran ganda terhadap satu kalimat. Misal pada kalimat " Rumah seniman yang antik itu akan segera dijual. Apa yang akan dijual? Rumah atau seniman yang antik? Frase yang antik menerangkan kata rumah atau seniman? Kalimat tersebut dapat menjadi efektif jika diubah menjadi sebagai berikut.

a) Rumah antik milik seniman itu akan segera dijual atau

b) Rumah seniman antik itu akan segera dijual.

\section{Ketidakjelasan Unsur Inti Kalimat}

Kalimat yang baik harus memiliki unsur pembangun yang lengkap, sekurangkurangnya memiliki subjek dan predikat. Jika predikat kalimat berupa kata kerja transitif, unsur kalimat yang disebut objek juga harus hadir. Unsur seperti keterangan bersifat sekunder, boleh tidak ada (Putrayasa, 2014). Perhatikan kalimat berikut.

a) Pembangunan itu // Subjek untuk menyejahterakan masyarakat.//

Keterangan

b) Bagi para mahasiswa yang akan mengikuti ujian//

Keterangan

//harus melunasi // uang SPP predikat objek

Secara sekilas, tidak ada yang salah dengan kalimat tersebut. Akan tetapi, setelah dianalisis lebih jauh, kalimat a) tidak memiliki unsur predikat, dan kalimat b) tidak memiliki unsur subjek. Kedua kalimat tersebut dapat dibenarkan menjadi:

a. (1) Pembangunan itu menyejahterakan masyarakat.
(2) Pembangunan itu bertujuan menyejahterakan masyarakat.

b Para mahasiswa yang akan

mengikuti ujian harus

melunasi uang SPP.

\section{Kemubaziran Preposisi dan Kata}

Ketidakefektifan kalimat sering disebabkan pemakaian kata depan yang tidak perlu. Misalnya penggunaan kata depan dari seperti pada ayah dari teman saya. Kata dari pada frasa tersebut dapat dihilangkan dan tidak akan mengubah arti.

Pemakaian kata depan dari dipengaruhi bahasa Belanda dalam hubungan posesif (Putrayasa, 2014). Oleh karena itulah banyak muncul kalimat dengan menggunakan kata dari yang seharusnya bisa ditiadakan tersebut. Misalnya:

a. Kaki dari meja itu patah.

b. Sepeda dari adik rusak berat karena berkarat

c. Anak dari Pak Fajar menjadi hakim.

Selain kata dari, kata oleh, daripada juga sering digunakan berlebihan. Ada pula pemakaian kata hari, tanggal, dan bulan yang dalam konteks tertentu tidak terlalu diperlukan. Misalnya:

d. Seminar itu akan berlangsung hingga (hari) Jumat mendatang.

e. Terhitung sejak (tanggal) 1 April 2006, ia diangkat menjadi CPNS.

f. Setiap (bulan) Oktober, Kantor Bahasa Gorontalo mengadakan Festival Bahasa Sastra.

Penggunaan kata hari, tanggal, dan bulan pada konteks berikut tidak dapat dihilangkan karena memiliki nilai informatif yang tinggi. Misalnya:

g. Dia akan datang pada hari Selasa.

h. Rapat itu akan diselenggarakan pada tanggal 30 Desember.

i. Proyek itu diperkirakan selesai pada bulan September.

\section{Kesalahan Nalar}

Nalar menentukan apakah kalimat yang kita tuturkan adalah kalimat yang logis atau tidak (Putrayasa, 2014). Kalimat salah nalar dapat kita lihat pada contoh berikut. 
a. Hadirin yang kami hormati. Kita tiba sekarang pada acara berikut yaitu sambutan bapak Bupati. Waktu dan tempat kami persilakan.

b. Dalam lomba itu, Romlah keluar sebagai juara pertama. Juara kedua diduduki Widi.

Kalimat a. jelas tidak logis. Siapa yang dipersilakan? Waktu dan tempat merupakan benda abstrak sehingga tidak tepat untuk dipersilakan. Pada kalimat b juga demikian. Jika diamati lebih lanjut akan timbul pertanyaan: siapakah juara kedua yang diduduki oleh Widi? Apakah yang menjadi juara kedua tersebut merupakan tempat duduk?

\section{Ketidaktepatan Bentuk Kata}

Dalam komunikasi sehari-hari, baik lisan maupun tertulis sering kita jumpai kata pedesaan, dan pemukiman. Jika dilihat dari proses pembentukan kata dan makna katanya, kata-kata itu tidak tepat. Jika yang dimaksud sebagai tempat tinggal penduduk desa, seharusnya yang tepat adalah perdesaan, dan permukiman jika yang dimaksud adalah tempat bermukim. Pedesaan dan pemukiman memang berkelas kata nomina tetapi artinya bukan menunjukkan tempat melainkan proses.

\section{Ketidaktepatan Makna Kata}

Ketidaktepatan makna kata dapat dilacak dengan mudah. Jika kata tersebut tidak dapat dipahami maknanya, pemakaiannya bisa saja tidak tepat.Misalnya contoh kalimat berikut.

Dia meregang nyawa dalam perjalanan ke rumah sakit.

Frasa meregang nyawa sering diartikan sebagai meninggal dunia, padahal dalam Kamus Besar Bahasa Indonesia edisi kelima, meregang nyawa berati sekarat.

\section{Pengaruh Bahasa Daerah}

Telah banyak bahasa daerah yang diserap ke bahasa Indonesia untuk memerkaya bahasa Indonesia, misalnya kata heboh, becus, lumayan, baruga, gembleng, cemooh, dan semarak. Hal yang perlu diperhatikan terkait penggunaan bahasa daerah tersebut adalah apakah bahasa daerah tersebut sudah berterima (dibakukan) atau belum.Jika belum, kita perlu dihindari penggunaannya agar tidak menimbulkan kemacetan dalam berkomunikasi sehingga informasi yang disampaikan menjadi tidak efektif.

\section{Pengaruh Bahasa Asing}

Seperti halnya bahasa daerah, bahasa asing juga turut memperkaya bahasa Indonesia. Kata-kata seperti kulkas, telat, setrika, porselen, toko, buku, kalender, dan sampo berasal dari bahasa asing yang saat ini tidak terasa sebagai kata-kata yang berasal dari bahasa asing. Akan tetapi, penggunaan bahasa asing juga perlu kehati-hatian.

\section{METODE}

Tulisan ini merupakan intisari dari penelitian kualitatif. Ada dua data yang digunakan, yaitu data primer dan data sekunder. Data primer berupa surat dinas (surat keluar) yang diarsipkan oleh staf tata usaha pemerintah Kabupaten Gorontalo periode 2014 sampai Juli 2019. Data sekunder berkaitan dengan dokumen yang berhubungan dengan tulisan ini. Untuk memperoleh data yang sesuai dengan permasalahan, diperlukan teknik pengumpulan data. Teknik pengumpulan data dalam tulisan ini adalah teknik dokumentasi. Teknik pengambilan sampel yang digunakan dalam tulisan ini adalah purposive sampling, yaitu pengambilan sampel berdasarkan tujuan penelitian.

Metode pengumpulan data tulisan ini adalah studi pustaka engan teknik catat. Analisis data menggunakaan analisis deskriptif dengan berdasar pada teori Kalimat Efektif

Langkah-langkah yang ditempuh berpijak pada ancangan analisis kualitatif untuk penelitian bahasa pada umumnya (Mahsun, 2006). Langkah-langkah tersebut, yaitu:

1. data yang telah diperoleh, dirangkum, diikhtisarkan, lalu dimasukkan ke dalam kategori sesuai variabel penelitian. Secara singkat, proses ini bisa disebut sebagai proses reduksi data,

2. penyajian data, 
3. membuat simpulan sementara dan menguji kembali dengan fakta atau fenomena di lapangan, dan

4. membuat pernyataan simpulan keseluruhan yang interpretatif berupa pemaparan dan penegasan simpulan tersebut.

\section{HASIL DAN PEMBAHASAN}

Data surat yang didokumentasikan direduksi menjadi 20 buah surat yang dianalisis. Ke-20 surat tersebut mewakili secara umum permasalahan yang diangkat dalam tulisan ini. Ke-20 surat tersebut ditelaah kalimat-kalimatnya, dan diperiksa apakah syarat awal (pemilihan kata/diksi dan penggunaan ejaan: penulisan huruf, penulisan kata dan tanda baca) dan syarat utama (struktur dan ciri) untuk membentuk kalimat secara efektif terpenuhi. Dari ke-20 surat tersebut, diperoleh 25 data kalimat yang selanjutnya diianalisis.

Berikut paparan data tersebut.

\section{Data 1}

Sehubungan dengan pelaksanaan Pameran

Pembangunan Kabupaten Gorontalo Expo 2015 dalam rangka HUT ke 341 Kabupaten Gorontalo 2015, maka dengan ini menugaskan yang nama-namanya tercantum dibawah ini untuk menjadi Penjaga Stand pada Pameran tersebut yang pelaksanaannya mulai tanggal $22 \mathrm{~s} / \mathrm{d}$ 26 November 2015. (surat Setda Bagian Pemerintahan, Kantor Bupati Gorontalo)

Pada data 1 tersebut terdapat banyak sekali kesalahan yang menyebabkan kalimat di dalamnya menjadi tidak efektif.

Pertama, dilihat dari pemilihan kata. Dalam kalimat data 1 tersebut terdapat kata pameran dan expo yang digunakan secara berlebih. Seharusnya, jika sudah menggunakan kata pameran, tidak perlu lagi menggunakan kata expo yang berarti sama. Kata expo juga adalah bahasa Inggris dan sudah dipadankan menjadi pameran.
Kesalahan kedua, masih dari segi pemilihan kata, pada kata penjaga stand. Kata stand sudah diserap $k e$ dalam bahasa Indonesia, yaitu stan tanpa huruf d.

Kesalahan ketiga, masih dari penggunaan kata, yaitu kata yang yang pada kalimat (yang nama-namanya ) seharusnya ditiadakan.

Kesalahan keempat, penggunaan kata maka. Dalam kalimat pada data 1, ini tidak ada kalimat yang mengandung hubungan sebab akibat.

Kesalahan kelima, kata mulai juga bisa dihilangkan karena tidak memberi informasi yang berarti.

Kesalahat keenam, dilihat penggunaan ejaan, pada penulisan kata bilangan tingkat pada HUT ke 341 Kabupaten Gorontalo yang tidak menggunakan garis hubung. Seharusnya ditulis HUT ke-341 Kabupaten Gorontalo, dengan garis hubung untuk memisahkan huruf (ke) dengan angka (341) (Direktorat Jenderal Peraturan Perundang-undangan, 2015).

Kesalahan ketujuh: penulisan huruf kapital pada kata penjaga stand. Seharusnya kedua kata tersebut tidak perlu diawali huruf kapital. Penjaga stand bukanlah profesi atau jabatan yang harus dituliskan dengan menggunakan huruf kapital.

Kesalahan kedelapan: penulisan huruf kapital pada kata pameran yang kedua. Seharusnya kata tersebut tidak diawali huruf kapital karena bukan merupakan awal kalimat dan juga tidak melambangkan nama (kegiatan).

Kesalahan kesembilan: huruf penulisan singkatan sampai dengan, s/d yang seharusnya ditulis s.d.

Kesalahan kesepuluh, penulisan kata dibawah yang tidak menggunakan spasi. Kata bawah menunjukkan tempat, bukan kata kerja sehingga $d i$ pada kata tersebut adalah preposisi, bukan awalan, sehingga penulisannya harus di pisah.

Kalimat data 1 tersebut belum efektif dari segi struktur kalimat. Kalimat tersebut tidak memiliki subjek, hanya keterangan (Sehubungan dengan pelaksanaan Pameran Pembangunan Kabupaten Gorontalo Expo 2015 dalam rangka HUT ke 341 Kabupaten 
Gorontalo 2015) dan predikat (menugaskan yang nama-namanya tercantum dibawah ini untuk menjadi Penjaga Stand pada Pameran tersebut yang pelaksanaannya mulai tanggal 22 s/d 26 November 2015).

Dari segi ciri kalimat efektif, kalimat pada data 1 ini juga tidak hemat (terlalu panjang. Dari aspek penekanan, kalimat ini juga tidak jelas. Apakah yang menjadi kegiatan inti dalam surat itu HUT ke-341 Kabupaten Gorontalo atau Pameran Pembangunan Kabupaten Gorontalo? Kalimat tersebut juga sebaiknya dipenggal menjadi dua kalimat.

Berikut perbaikan kalimat data 1.

Sehubungan dengan pelaksanaan Pameran Pembangunan Kabupaten Gorontalo Tahun 2015, (dalam rangka HUT ke-341 Kabupaten Gorontalo 2015), kami menugaska nama-nama yang tercantum di bawah ini untuk menjadi penjaga stan pameran. Pameran tersebut akan dilaksanakan pada tanggal 22 s.d. 26 November 2015.

\section{Data 2}

Sehubungan dengan Pelaksanaan Rapat evaluasi Triwulan I Program/Kegiatan Pembangunan, Pemerintahan dan Keuangan Tahun Anggaran 2015 Kabupaten Gorontalo, yang dilaksanakan pada hari Selasa, 28 April 2015, maka dengan ini kami dimohonkan untuk dapat meminjamkan Gedung Kasmat Lahay, Sound Sistem dan Kursi sebanyak 500 buah. (surat Setda Bagian Pembangunan dan Pengendalian Program, Kantor Bupati Gorontalo)

Pada data 2 tersebut juga terdapat banyak sekali kesalahan yang menyebabkan kalimat pada data ini menjadi tidak efektif.

Pertama dilihat dari pemilihan kata. Dalam kalimat data 2 tersebut terdapat kata hari yang sebetulnya bisa dihilangkan karena tidak mengurangi nilai informasi kalimat.

Kesalahan kedua, penggunaan kata dimohonkan membuat kalimat ini menjadi tidak bernalar dan rancu Jika dicermati, siapa yang bermohon dan siapa yang dimintai permohonan? Mengapa harus menggunakan kata kami dimohonkan untuk dapat meminjamkan padahal pihak yang menulis suratlah yag bermohon? Bentuk kata dimohonkan juga keliru.

Kesalahan ketiga, masih dari segi kesalahan nalar, kata-kata meminjamkan Gedung Kasmat Lahay, Sound Sistem dan Kursi sebanyak 500 buah. Apakah yang ingin dipinjam Gedung Kasmat Lahay sebanyak 500 buah, Sound System sebanyak 500 buah, dan kursi 500 buah? Penempatan sebanyak 500 buah kursi di akhir kalimat menimbulkan penafsiran ganda.

Kesalahan keempat, penulisan istilah sound system, yang sudah yang tidak ditulis miring sebagaimana aturan penulisan bahasa asing dalam dokumen resmi. Selain itu, kedua kata ini menggabungkan bahasa asing (SoundInggris) dengan bahasa Indonesia : sistem.

Kesalahan kelima, dari segi ciri kalimat efektif, kalimat ini tidak efektif karena tidak memenuhi ciri kehematan.

Kesalahan keenam, penggunaan huruf kapital. Seharusnya kata evaluasi pada Rapat evaluasi Triwulan I Program/Kegiatan Pembangunan, Pemerintahan dan Keuangan Tahun Anggaran 2015 Kabupaten Gorontalo, ditulis dengan diawali huruf kapital karena bagian dari nama (kegiatan).

Kesalahan ketujuh, penggunaan kata maka. Dalam kalimat pada data 2, ini tidak ada kalimat yang mengandung hubungan sebab akibat.

Berikut perbaikan kalimat data 2.

Sehubungan dengan Pelaksanaan Rapat Evaluasi Triwulan I Program/Kegiatan Pembangunan, Pemerintahan dan Keuangan Tahun Anggaran 2015 Kabupaten Gorontalo, yang dilaksanakan pada Selasa, 28 April 2015, dengan surat ini kami memohon Bapak/lbu dapat meminjamkan Gedung Kasmat Lahay, Sound System dan 500 kursi.

\section{Data 3}




Sehubungan dengan
Peringatan pelaksanaan
Kemerdekaan RI ke-69 Tahun 2015
Tingkat Kabupaten Gorontalo, maka perlu
disampaikan hal-hal sebagai berikut.
(surat Setda Bagian Umum, Kantor Bupati
Gorontalo)

Pada data 3 tersebut juga terdapat kesalahan yang menyebabkan kalimat di dalamnya menjadi tidak efektif.

Pertama, kesalahan nalar pada Peringatan HUT Proklamasi Kemerdekaan RI ke-69 Tahun 2015 Tingkat Kabupaten Gorontalo. Apakah yang yang dirayakan? Ulang tahun kemerdekaan RI atau proklamasi kemerdekaan RI-pernyataan kemerdekaan RI? Pertanyaan yang timbul selanjutnya, ada berapakah Republik Indonesia? Bukankah Republik Indonesia hanya ada satu? Lalu, mengapa ada RI ke-69? Perlu diketahui bahwa penulisan kemenunjukan urutan sehingga jika ditulis RI ke69, berarti ada banyak RI, dan kali ini, yang merayakan ulang tahun adalah RI yang nomor 69.

Kesalahan kedua, dari segi struktur, kalimat ini juga tidak memiliki subjek.

Kesalahan ketiga, terkait dengan ketiadaan subjek, kalimat ini juga terkontaminasi bentuk aktif dan pasif. Kalimat perlu disampaikan halhal sebagai berikut sebaiknya ditulis dalam bentuk aktif agar subjek jelas.

Kesalahan keempat, penulisan Tahun 2015 yang sebenarnya bisa dihilangkan agar kalimat ini tidak rancu. Apakah ada perayaan HUT RI yang lain di tahun yang sama? Bukankah hari ulang tahun hanya dilakukan satu kali dalam setahun?

Kesalahan kelima, penulisan kata sebagai yang tidak perlu pada kata sebagai berikut. Kata sebagai tersebut dapat dihilangkan dan tidak mengubah nilai informasi kalimat ini.

Berikut perbaikan data 3.

Sehubungan dengan pelaksanaan

Peringatan HUT ke-69 RI Tingkat

Kabupaten Gorontalo, kami perlu menyampaikan hal-hal berikut.

\section{Data 4}

Demikian disampaikan sebagai laporan atasnya. (surat Setda Bagian Kesejahteraan Masyarakat Kantor Bupati Gorontalo)

Data 4 tersebut adalah salah satu contoh penutup surat yang keliru. Kalimat tersebut sangat rancu dari segi struktur, diksi dan logika.

Kesalahan pada data 4 ini adalah ketidaktepatan penggunaan partikel -nya. Perlu diketahui partikel -nya adalah partikel kepemilikan sehingga hanya melekat pada kata benda (misalnya: rumahnya, laporannya, mobilnya). Sementara pada kalimat tersebut, nya melekat pada kata atas.

Berikut perbaikan data 4.

Demikian kami sampaikan. Atas perhatian Bapak, kami mengucapkan terima kasih.

\section{Data 5}

Demikian Laporan ini disampaikan kepada bapak untuk perlunya seraya memohon petunjuk lebih lanjut. (surat Setda Bagian Hukum Kantor Bupati Gorontalo)

Serupa dengan data 4, data 5 ini juga merupakan contoh penutup surat yang tidak efektif. Kita perhatikan penggunaan partikel nya lagi-lagi tidak tepat (kesalahan pertama).

Kesalahan kedua adalah penulisan huruf kapital yang mengawali kata laporan yang tidak tepat.

Kesalahan ketiga, penulisan kata sapaan (bapak) yang tidak diawali huruf kapital.

Kesalahan keempat, kalimat ini terlalu panjang dan memuat dua informasi yang berbeda (satu mengenai penyampaian laporan, Sn kedua mengenai permohonan petunjuk). Sehingga kata-kata seraya memohon petunjuk lebih lanjut dapat dihilangkan karena tidak memberi arti apa-apa selain hanya berpanjangpanjang kata.

Berikut perbaikan data 5. 
Demikian laporan ini kami sampaikan. Atas perhatian Bapak, kami mengucapkan terima kasih.

\section{Data 6}

Demikian disampaikan, atas kehadirannya diucapkan terima kasih. (surat Setda Bagian Ekonomi Kantor Bupati Gorontalo)

Serupa dengan data 4 dan 5

data 6 ini juga merupakan contoh penutup surat yang keliru. Partikel - nya dalam data ini memang melekat pada kata benda (kehadiran). Akan tetapi dari segi makna, kalimat tersebut rancu. Nya siapa yang dimaksud? Kesalahan kedua, kata-kata demikian disampaikan juga dapat dihilangkan karena tidak menambah informasi yang berarti.

Berikut perbaikan data 6

Atas kehadiran Bapak/Ibu, kami mengucapkan terima kasih.

\section{Data 7.}

Dan tanah tersebut oleh keluarga Ariel Humonggio di klaim sebagai milik mereka dan meminta ganti rugi. (surat Setda Bagian Hukum Kantor Bupati Gorontalo)

Kesalahan pertama yang terdapat pada data 7 ini adalah penggunaan kata penghubung dan di awal kalimat.

Kesalahan kedua, kontaminasi bentuk aktif dan pasif, yang menyebabkan kesalahan ketiga, kesalahan nalar. Dari kalimat tersebut, siapakah yang meminta ganti rugi? Tanah, bukan?

Kesalahan keempat, penulisan diyang seharusnya tidak dipisah dari kata klaim, di- pada kata tersebut merupakan awalan, bukan preposisi, sehingga penulisannya harus dirangkai.

Kesalahan kelima, penulisan sebagai milik mereka lewah karena sebelumnya sudah ada kata klaim yang mengandung makna serupa.

Berikut perbaikan data 7.

Keluarga Ariel $\begin{gathered}\text { Humonggio } \\ \text { mengklaim tanah tersebut dan } \\ \text { meminta ganti rugi. }\end{gathered}$

\section{Data 8}

Setelah di lakukan monitoring ke lokasi yang di permasalahkan ternyata Ariel Humonggio tidak memiliki bukti yang tidak cukup. (surat Setda Bagian Hukum Kantor Bupati Gorontalo)

Kesalahan pertama yang terdapat pada data 8 tersebut adalah dari segi penulisan ejaan: penulisan di lakukan yang seharusnya ditulis serangkai karena di pada kata tersebut merupakan awalan, bukan preposisi.

Berbeda dengan kata di permasalahkan (kesalahan kedua). Penulisan $d i$ harus dirangkai dengan kata permasalahkan karena di merupakan awalan.

Kesalahan ketiga, penggunaan diksi monitoring. Kata monitoring telah ada padanannya dalam bahasa Indonesia yaitu pemantauan. Jika ingin dituliskan dalam bahasa Inggris, kata tersebut karus ditulis miring.

Kesalahan keempat, adalah kesalahan nalar, disebabkan penggunaaan kata tidak yang dobel. Bukankah Ariel Humonggio tidak memiliki bukti yang tidak cukup berarti Ariel Humonggio memiliki bukti yang cukup? Secara logika, dalam kalimat tersebut, pesan yang ingin disampaikan pihak penulis surat adalah bahwa Ariel Humonggio tidak memiliki bukti yang cukup.

Kesalahan kelima adalah dari segi penggunaan ejaan : tanda baca. Seharusnya, antara kata dipermasalahkan dan ternyata ada tanda baca koma.

Berikut perbaikan data 8 .

a. Setelah dilakukan monitoring ke lokasi yang dipermasalahkan, ternyata Ariel Humonggio tidak memiliki bukti yang cukup.

b. Setelah dilakukan pemantauan ke lokasi yang dipermasalahkan, ternyata Ariel Humonggio tidak memiliki bukti yang cukup. 


\section{Data 9}

Maka dengan berdasarkan hasil dari Tim Monitoring mengharapkan kepada Ariel Humonggio untuk mengajukan laporan kembali kepada pihak yang berwajib. (surat Setda Bagian Hukum Kantor Bupati Gorontalo)

Dari segi struktur, diksi dan logika, kalimat pada data 9 ini sangat tidak efektif.

Kesalahan pertama, dari segi struktur, dapat dipertanyakan mengenai subjek kalimat ini. Siapakah yang mengharap Ariel Humonggio untuk mengajukan laporan kembali kepada pihak yang berwajib?

Kedua, kesalahan bentuk kata mengharapkan. Bentuk kata mengharapkan di sini tidak tepat karena diikuti oleh objek hidupyang bergerak. Sementara imbuhan mekan disertai dengan objek tidak bergerak. Mari kita perhatikan contoh berikut.

\section{a. Dial/ mengirimkan//buku/l $\begin{array}{lll}S & P & O\end{array}$ kepada saya. Keterangan}

\section{b. Dia // $\underline{\text { mengirimi } / / s a y a ~ b u k u . ~}$ $S \quad P \quad O$ Pelengkap}

Dari kedua kalimat ini jelas bahwa meskipun me-kan dan me-i sama-sama disertai objek, posisi objek tersebut diisi oleh dua hal yang berbeda. Kata mengharapkan lebih tepat bial diganti dengan berharap.

Kesalahan ketiga adalah penggunaan kata maka, dengan dan untuk yang tidak perlu. Kesalahan keempat adalah kata kembali yang seharusnya muncul sebelum kata mengajukan, bukan setelah kata itu.

Berikut perbaikan data 9 .

Berdasarkan hasil pantauan, Tim Monitoring berharap Ariel
Humonggio kembali mengajukan laporan kepada pihak yang berwajib.

\section{Data 10}

Dalam rangka pelaksanaan Isra Mi'raj Nabi Muhammad SAW 1436 H/2015 tingkat Kab.Gorontalo yang dilaksanakan secara Nasional dan tradisional, maka dengan ini mengundang Bapak/Ibu untuk menghadiri kegiatan tersebut yang Insya Allah dilaksanakan pada.... (surat Setda Bagian Kesejahteraan Masyarakat Kantor Bupati Gorontalo)

Kesalahan pertama pada data ini adalah dari segi diksi, yaitu penggunaan kata mi'raj. Kata ini telah dipadankan ke dalam bahasa Indonesia menjadi mikraj.

Kesalahan kedua, penulisan SAW setelah Nabi Muhammad seharusnya Saw..

Kesalahan ketiga adalah penulisan Tahun 2015 setelah $1436 \mathrm{H}$ tidak perlu karena itu lewah. Kesalahan keempat adalah penggunaan kata-kata yang dilaksanakan secara Nasional dan tradisional merupakan pemborosan (informasi yang tidak berarti apaapa).

Kesalahan kelima adalah penggunaan kata maka yang tidak tepat. Dari segi struktur, kalimat ini juga tidak memiliki subjek (kesalahan keenam). Bukankah setelah membaca pertanyaan ini akan timbul pertanyaan mengenai siapa yang mengundang?

Kesalahan ketujuh, kalimat ini juga tidak hemat. Untuk membuat kalimat ini efektif, kalimat ini bisa dipengggal menjadi dua kalimat. Satu untuk informasi undangan diadakannya isra mikraj, dan kedua adalah informasi mengenai waktu dan tempat pelaksanaan.

Kesalahan kedelapan adalah penulisan kata Insya Allah yang seharusnya ditulis insyaallah, sebagaimana penulisan alhamdulillah dan masyaallah. Kesalahan kesembilan adalah kata pelaksanaan. Kata pelaksanaan tidak tepat konteksnya karena Isra Mikraj tidak lagi dilaksanakan (hanya satu kali 
pada saat Nabi Muhammad hijrah). Umat Islam hanya memperingatinya, lebih tepat digunakan kata peringatan. Sehingga, kalimat data 10 ini dapat diperbaiki sebagai berikut.

a. Dalam rangka peringatan Isra Mikraj Nabi Muhammad Saw. 1436 H Tingkat Kab.Gorontalo, yangi insyallah dilaksanakan pada..., bersama surat ini kami mengundang Bapak/Ibu untuk menghadiri kegiatan tersebut.

b. Bersama surat ini, kami mengundang Bapak/Ibu untuk menghadiri peringatan Isra Mikraj Nabi Muhammad Saw. 1436 H Tingkat Kab.Gorontalo. Kegiatan tersebut akan dilaksanakan pada....

\section{Data 11}

Sehubungan dengan persiapan pelaksanaan Diklat Sertifikasi Tuntutan Ganti RUGI Angkatan III Tahun 2015 yang dilaksanakan oleh Yayasan Patria Artha, maka dengan ini mengundang kepada Saudara untuk mengikuti pertemuan dimaksud sekaligus membawa daftar peserta diklat, dengan ketentuan waktu sebagai berikut:... (Surat Setda bagian Kesejahteraan Masyarakat Kantor Bupati Gorontalo)

Kesalahan pertama pada data 11 tersebut adalah penggunaan huruf kapital yang berlebihan/tidak tepat pada kata rugi. Kata rugi tersebut cukup ditulisan Rugi.

Kesalahan kedua adalah dari segi struktur. Kalimat ini tidak memiliki subjek.

Kesalahan ketiga, kalimat ini terlalu panjang serta terlau banyak informasi yang ingin disampaikan sekaligus. Kesalahan keempat, penggunaan kata kepada lewah, dan bisa dihilangkan karena kata mengundang adalah kata kerja transitif yang memerlukan objek langsung, bukan pelengkap. Sehingga data 11 tersebut dapat diperbaiki sebagai berikut.

Sehubungan dengan persiapan pelaksanaan Diklat Sertifikasi Tuntutan
Ganti Rugi Angkatan III Tahun 2015 yang dilaksanakan oleh Yayasan Patria Artha, dengan surat ini kami mengundang Saudara untuk mengikuti pertemuan tersebut. Kami berharap Saudara membawa daftar peserta diklat, dengan ketentuan waktu sebagai berikut:...

\section{Data 12}

$\begin{array}{lr}\text { Dalam Rangka } & \begin{array}{r}\text { Pelaksanaan } \\ \text { Musyawarah rencanaan }\end{array} \\ \text { Pembangunan } & \text { Daerah } \\ \text { (MUSRENBANGDA) } & \text { Kabupaten } \\ \text { Gorontalo Tahun 2015, maka dengan } \\ \text { ini dimohon kehadirannya pada acara } \\ \text { yang dimaksud, yang akan } \\ \text { dilaksanakan pada:.... (surat Setda } \\ \begin{array}{l}\text { Bagian Ekonomi Kantor Bupati } \\ \text { Gorontalo) }\end{array}\end{array}$

Kesalahan pertama pada kalimat ini adalah dari segi struktur. Kalimat ini tidak memiliki subjek dan objek.

Kesalahan kedua, kalimat ini juga tidak hemat. Kesalahan ketiga adalah penulisan huruf kapital pada kata rangka. Kata tersebut tidak perlu diawali dengan huruf kapital.

Kesalahan keempat adalah adanya kontaminasi bentuk aktif dan pasif.

Kesalahan kelima adalah penggunaan tanda baca titik dua setelah kata pada. Padahal, kalimat tersebut kalimat rincian.

Agar efektif, kalimat tersebut perlu diubah menjadi:

$\begin{array}{lr}\begin{array}{l}\text { Dalam rangka } \\ \text { Musyawarah }\end{array} & \begin{array}{r}\text { Pelaksanaan } \\ \text { Perencanaan }\end{array} \\ \text { Pembangunan } & \text { Daerah } \\ \text { (MUSRENBANGDA) } & \text { Kabupaten } \\ \text { Gorontalo Tahun 2015, dengan surat } \\ \text { ini kami memohon kehadiran } \\ \begin{array}{l}\text { Bapak/Ibu. Acara tersebut akan } \\ \text { dilaksanakan pada.... }\end{array}\end{array}$

\section{Data 13}


Diharapkan Kepada Bapak/Ibu

Kepala SKPD untuk hadir tepat waktu ulangi tepat waktu (surat Bappeda)

Pada kalimat data 13 tersebut, terdapat banyak kesalahan yang membuat kalimat ini tidak efektif.

Pertama penulisan huruf kapital pada Kepada, seharusnya kepada. Kesalahan kedua, penggunaan sapaan (Bapak/Ibu) pada jabatan (Kepala SKP).

Kesalahan ketiga yakni pemborosan dengan adanya ulangi tepat waktu.

Berikut kalimat perbaikan untuk data 13 tersebut.

Diharapkan kepada Bapak/Ibu Kepala SKPD untuk hadir tepat waktu.

\section{Data 14}

mengingat data tersebut sangat dibutuhkan untuk mempercepat proses administrasi pengelolalan barang milik daerah serta tertibnya pengelolaan aset Pemerintah Kabupaten Gorontalo diharapkan untuk segera menyampaikan data dimaksud.

(surat Setda Bagian Ekonomi Kantor Bupati Gorontalo)

Kesalahan pertama yang terdeteksi pada kalimat tersebut adalah adanya kontaminasi bentuk aktif dan pasif. Kontaminasi tersebut menyebakan kesalahan kedua: tidak jelas siapa yang harus menyampaikan data, dan siapa yang meminta data.

Kalimat pada data 14 ini dapat diperbaiki menjadi:

mengingat data tersebut sangat
dibutuhkan untuk mempercepat proses
administrasi pengelolalan barang
milik daerah serta tertibnya
pengelolaan aset Pemerintah
Kabupaten Gorontalo, Bapak/Ibu
diharapkan segera menyampaikan
datayang dimaksud.

\section{Data 15}

Dari Lembaga Adat Kabupaten Gorontalo hanya berfungsi memfasilitasi acaranya. (surat Setda bagian Kesra)

Kalimat pada data 15 tersebut tidak efektif karena ada kata dari di awal kalimat (kesalahan pertama). Kesalahan kedua, kalimat tersebut tidak memiliki subjek, kanya keterangan dan predikat. Lalu, siapa yang memfasilitasi acaranya?

Berikut perbaikan data 15 .

Lembaga Adat Kabupaten Gorontalo hanya berfungsi memfasilitasi acara.

\section{Data 16}

Sehubungan dengan selesainya kegiatan tersebut kami memaklumkan bahwa acaranya telah berlangsung dengan sukses. (surat Setda Bagian Kesejahteraan Masyarakat)

Dari segi makna, kalimat ini sangat rancu. (kesalahan pertama). Penggunaan kata memaklumkan juga tidak tepat (kesalahan kedua). Kata memaklumkan telah bergeser maknanya. Tidak lagi berarti mengabarkan atau memberitahukan sebagaimana makna kata tersebut dalam Kamus Umum Bahasa Indonesia karangan Poerwadarminta (Poerwadarminta, 1985) melainkan berati membuat maklum atau menjadi maklum (KBBI V). Kata tersebut bisa diganti dengan memberitahukan.

Berikut Perbaikan data 16.

Sehubungan dengan selesainya kegiatan tersebut, kami ingin memberitahukan kepada Bapak/Ibu bahwa acara tersebut telah berlangsung dengan sukses.

\section{Data 17}

Khusus bagi tenaga dari unsur lembaga Adat yang digiatkan langsung pada acara tersebut, dimohonkan bantuan alakadarnya sebagai bentuk terima kasih pada masing- masing yang bersangkutan. (surat Setda Bagian Kesejahteraan Masyarakat) 
Dari segi struktur, kalimat ini tidak memiliki subjek (kesalahan pertama). Kesalahan kedua adalah penggunaan kata dimohonkan yang tidak tepat.

Kesalahan ketiga adalah penggunaan kata masing-masing yang tidak tepat. Kata masingmasing pada kalimat tersebut lewah, bisa dihilangkan. Perlu diketahui bahwa penulisan kata masing-masing muncul setelah kata benda, seperti pada contoh berikut.

a. Para siswa diharapkan kembali ke kelas masing-masing.

b. Tiap-tiap siswa wajib membawa prakarya.

Kesalahan keempat adalah penulisan alakadarnya yang seharusnya di pisah : ala kadarnya. Kesalahan kelima, kalimat ini tidak memiliki objek.

Kesalahan keenam, penggunaan kata yang bersangkutan tidak tepat dan lewah. Kata tersebut dapat dihilangkan karena tidak mengandung informasi apa-apa.

Berikut perbaikan data 17

Kami memohon bantuan ala kadarnya untuk diberikan kepada tenaga dari unsur lembaga adat yang telah bergiat pada acara tersebut.

\section{Data 18}

Demikian harapan kami semoga mendapatkan perhatian seperlunya. (surat Setda Bagian Kesejahtreaan Masyarakat Kantor Bupati Gorontalo).

Kalimat penutup surat pada data 18 tersebut juga rancu. Data 18 tersebut dapat diperbaiki menjadi

(Demikian harapan kami.)
perhatian Bapak/lbu,
mengucapkan terima kasih.

\section{Data 19}

Dalam rangka pemenuhan data kinerja Bupati Gorontalo yang tertuang dalam Laporan Penyelenggaraan Daerah (LPPD) Tahun 2014 khususnya yang berkenaan dengan bidang perdagangan. (surat Setda Bagian Pemerintahan Kantor Bupati Gorontalo)

Dari segi struktur, kaliamt pada data 19 tersebut tidak efektif. Kaliamt tersebut hanya memuat unsur keterangan.

\section{Data 20}

a. Sehubungan dengan adanya permohonan penerbitan sertipikat Atas nama Astin Pandju yang terletak di Desa Hulawa, Kecamatan Telaga, Kabupaten Gorontalo, dalam permohonan tersebut pemohon melampirkan Putusan Nomor 35/Pdt.G/2016/PN Lbo tanggal 29 November 2016.

b. Menindaklanjuti permohonan tersebut mohon bantuan untuk informasi apakah ada upaya banding atau upaya hukum setelah ditetapkan putusan tersebut (surat Kantor Pertanahan Kabupaten Gorontalo).

Kalimat pada data 20 (a) tersebut tidak efektif. Mengapa? Pertama, penulisan huruf kapital pada kata atas yang tidak seharusnya.

Kedua, apakah yang terletak di Desa Hulawa, Kecamatan Telaga Kabupaten Gorontalo? Tanah atau sertipikatnya? Jika dicermati, yang terletak di Desa Hulawa, Kecamatan Telaga Kabupaten Gorontalo pada kalimat tersebut adalah sertipikat, bukan tanah. Kalimat a tersebut juga dapat dipenggal menjadi dua bagian.

Ketiga, kalimat tersebut tidak memiliki subjek. Sehingga perbaikannya menjadi

$$
\begin{aligned}
& \text { Sehubungan dengan adanya } \\
& \text { permohonan penerbitan sertipikat atas } \\
& \text { nama Astin Pandju untuk tanah yang } \\
& \text { terletak di Desa Hulawa, Kecamatan } \\
& \text { Telaga, Kabupaten Gorontalo (dalam }
\end{aligned}
$$




\author{
permohonan tersebut, pemohon \\ melampirkan Putusan Nomor \\ 35/Pdt.G/2016/PN Lbo tanggal 29 \\ November 2016),
}

Kalimat b merupakan lanjutan dari kalimat a sehingga kata menindaklanjuti bisa dihilangkan. Dalam kalimat tersebut (kesalahan keempat tidak jelas siapa yang dimohon bantuannya)

Berikut perbaikan data $20 \mathrm{~b}$

melalui surat ini, kami memohon bantuan Bapak/Ibu untuk memberikan informasi terkat adanya upaya banding atau upaya hukum setelah ditetapkan putusan tersebut.

Jika digabung, perbaikan kaliat 20a dan 20b akan menjadi

Sehubungan dengan adanya permohonan penerbitan sertipikat atas nama Astin Pandjuuntuk tanah yang terletak di Desa Hulawa, Kecamatan Telaga, Kabupaten Gorontalo (dalam permohonan tersebut, pemohon melampirkan Putusan Nomor 35/Pdt.G/2016/PN Lbo tanggal 29 November 2016), melalui surat ini, kami memohon bantuan Bapak/Ibu untuk memberikan informasi terkat adanya upaya banding atau upaya hukum setelah ditetapkan putusan tersebut.

\section{Data 21}

Menindaklanjuti Laporan Masyarakat Penggarap HGU Ayula Desa Molowahu, Kecamatan Tibawa, maka dengan hormat disampaikan bahwa Komisi I Bidang Pemerintahan Hukum dan HAM, dan Pertanian DPRD Kabupaten Gorontalo akan mengadakan Rapat Dengar Pendapat dengan Pihak terkait yang akan dilaksanakan pada :

Hari/ Tanggal : Senin, 08 Juli 2019

Waktu : Pukul 09.00 Wita s/d Selesai

Tempat: Ruang Rapat DPRD Kab. Gorontalo. (surat DPRD Kabupaten Gorontalo)
Dari segi penggunaan ejaan, kalimat pada Data 21 belum efektif. Hal tersebut dapat kita lihat pada bagian Hari/Tanggal (kesalahan pertama).

Dalam format surat undangan, kata hari dipisahkan oleh tanda baca koma, bukan garis miring. Garis miring berarti atau sedangkan pada konteks kata tersebut bukan pilihan. Kata tanggal juga tidak perlu diawali dnegan huruf kapital.

Kemudian kesalahan kedua, penulisan tanggal seharusnya $8 \mathrm{Juli}$, bukan $08 \mathrm{Juli}$. Kesalahan ketiga adalah penggunaan kata Wita yang boleh dihilangkan. Undangan ini ditujukan kepada mereka yang berdomisili di wilayah Gorontalo. Hal itu berarti antara yang diundang dan yang mengundang berada di zona waktu yang sama.

Kesalahan keempat adalah penggunaan tanda baca titik dua setelah kata pada. Padahal kalimat berikutnya bukan merupakan rincian. Kesalahan kelima adalah penulisan huruf kapital pada kata pihak tidak tepat.

Kesalahan keenam adalah penulisan singkatan sampai dnegan yang masih menggunakan garis miring. Padahal, aturan penulisan singkatan tidak demikian. Dalam penulisan singkatan, tanda titik mengakhiri srtiap kata yang disingkat. penggunaan kata selesai.

Berikut perbaikan data 21

Menindaklanjuti Laporan Masyarakat
Penggarap HGU Ayula Desa
Molowahu, Kecamatan Tibawa,
dengan hormat kami sampaikan
bahwa Komisi I Bidang Pemerintahan
Hukum dan HAM, dan Pertanian
DPRD Kabupaten Gorontalo akan
mengadakan Rapat Dengar Pendapat
dengan pihak terkait yang akan
dilaksanakan pada

Hari, tanggal : Senin, 8 Juli 2019

Waktu : Pukul 09.00 Wita s.d selesai

Tempat: Ruang Rapat DPRD Kab. Gorontalo. (surat DPRD Kabupaten Gorontalo)

\section{Data 22}


Terkait dengan upaya tersebur, BNN

Kabupaten Gorontalo melakukan Kampanye Stop Narkoba dengan membagikan Stiker dan doorprize (kaos) HANI 2019 kepada Pengemudi Bentor di seputaran " "Menara Keagungan Limboto” (Surat BNN Kabupaten Gorontalo)

Dari data 22 tersebut tampak kesalahan dari penggunaan diksi, yakni kata doorprize lebih dipilih pengonsep surat alihalih kata hadiah kejutan (kesalahan pertama). Kesalahan kedua, penggunaan kata kaos (seharusnya kaus).

\section{Data 23}

Demikian disampaikan untuk menjadi maklum. (surat Kantor Pertanahan Kabupaten Gorontalo).

Dari data 23 ini tampak penggunaan kata untuk menjadi maklum yang menyebabkan kalimat ini menjadi rancu. Siapakah yang diharapkan menjadi maklum? Kalimat tersebut dapat diperbaiki menjadi Demikian kami sampaikan.

\section{Data 24}

Demikian disampaikan atas berkenan sebelumnya diucapkan terima kasih. (Surat BNN Kabupaten Gorontalo).

Dari data 24 ini tampak adanya kerancuan. Atas berkenan siapa? Kerancuan ini disebabkan ketiadaan unsur objek dalam kalimat ini. Kalimat ini juga tampak memperlihatkan pengaruh bahasa lisan (bahasa daerah yang memengaruhi bahasa tertulis. Kesalahan selanjutnya adalah penggunaan kata berkenan, alih-alih perkenan. Kalimat tersebut dapat diperbaiki menjadi

Demikian kami sampaikan. Ats perkenan Bapak/Ibu, kami ucapkan terima kasih.
Demikian disampaikan, atas bantuan di ucapkan terima kasih. (surat Kantor Pertanahan Kabupaten Gorontalo)

Dari data 25 ini juga tampak adanya kerancuan. Ketiadaan unsur objek menyebabkan kalimat ini rancu. Selain itu, penulisan awalan di yang ditulis terpisah (seharusnya dirangkai) Kalimat tersebut dapat diperbaiki menjadi

Demikian kami sampaikan. Ats perkenan Bapak/Ibu, kami ucapkan terima kasih.

Pada bagian awal tulisan init telah dijelaskan bahwa penggunaan bahasa pada surat dinas memerlukan kecermatan dalam penggunaan bahasanya. Penggunaan bahasa tersebut merupakan faktor penentu terjalinnya kelancaran komunikasi antara pengirim surat dengan penerima surat. Oleh karena itu, penulis surat dinas sebaiknya memahami kaidah-kaidah bahasa Indonesia yang baik dan benar.

Dari 25 data yang dianalisis pada tulisan ini, masih terdapat banyak kesalahan yang menyebabkan kalimat-kalimat dalam surat dinas tidak efektif. Bahkan, tampak beberapa kesalahan berulang seperti penggunaan tanda titik dua setelah kata pada, kekeliruan penulisan preposisi di dan awalan $k e-$, kontaminasi bentuk aktif dan pasif, penulisan singkatan sampai dengan yang keliru, dan penghilangan salah satu unsur utama kalimat, baik subjek maupun objek, dan penggunaan partikel -nya yang tidak tepat pada penutup surat

Perulangan kesalahan tersebut bisa jadi sesuai dengan apa yang dipaparkan oleh Badudu(J.S. Badudu, 1993), dalam kaitannya dengan pleonasme, Dalam hal ini, penulis surat tidak sadar bila apa yang dibuatnya/ditulisnya berlebihan atau keliru dan penulis/pembuat surat tidak tahu jika pada yang dibuat/ditulisnya itu keliru.

Selain itu tampak bahwa pengaruh bahasa asing (Inggris masih kuat). Penulis surat lebih memilih menggunakan kata stand daripada stan; kata monitoring daripada 
pemantauan, kata doorprize daripada hadiah kejutan.

Penggunaan preposisi dari misalnya pada data 15 (Dari Lembaga Adat Kabupaten Gorontalo hanya berfungsi memfasilitasi acaranya.) menunjukkan pengaruh bahasa asing (Belanda) yang kental. Meskipun pada konteks tertentu, kata dari justru tidak boleh dihilangkan.

Dari ke-25 data tersebut, dapat diketahui faktor-faktor penyebab ketidakefektifan kalimat dalam bahasa surat di Lingkungan Pemerintah Kabupaten Gorontalo, yakni kontaminasi atau kerancuan, pleonasme, ambiguitas, ketidakjelasan subjek, kemubaziran preposisi dan kata, kesalahan nalar, ketidaktepatan bentuk kata, ketidaktepatan makna kata, dan pengaruh bahasa daerah, dan pengaruh bahasa asing.

\section{PENUTUP}

Dari paparan pembahasan pada bagian sebelumnya, tampak beberapa kesalahan berulang seperti penggunaan tanda titik dua setelah kata pada, kekeliruan penulisan preposisi di dan awalan di- , kontaminasi bentuk aktif dan pasif, penulisan singkatan sampai dengan yang keliru, penghilangan salah satu unsur utama kalimat, baik subjek maupun objek, dan penggunaan partikel-nya yang tidak tepat pada penutup surat. Kesalahan yang paling banyak adalah penghilangan subjek.

Temuan penelitian ini mengantarkan kita pada simpulan bahwa bahasa Indonesia yang baik dan benar dapat dilihat setidaknya dari tiga hal, yaitu struktur, diksi, maupun ejaannya, demikian juga dalam surat. Penggunaan bahasa dalam surat memerlukan kecermatan dan ketepatan baik di dalam penerapan kaidah ejaan, struktur, bentuk kata dan pemilihannya serta unsur bahasa dalam struktur kalimat.

Kalimat-kalimat yang benar dari segi

struktur bahasanya, belum tentu sudah efektif kalimatnya, apalagi jika memang sudah kacau dari segi struktur. Untuk mengatasi ketidakefektifan dalam bahasa surat dinas, diperlukan penyuluhan penggunaan bahasa Indoensia dalam surat dinas secara sistematis dan berkesinambungan, apalagi telah ada pasal 33 UU No. 24 Tahun 2009 yang mengatur hal tersebut.

\section{DAFTAR PUSTAKA}

Adiyasa, dkk. (2018). Penggunaan Bahasa Indonesia pada Surat Dinas Pembelajaran Menulis Surat di Sekolah. Jurnal Pendidikan Bahasa Dan Sastra Indonesia Undiksha, 8, 334-343.

https://doi.org/10.23887/jjpbs.v8i2.20628

B., M. A. (2014). Analisis Kesalahan Diksi dan Kalimat dalam Surat Dinas pada Kantor Wali Kota Makassar Provinsi Sulawesi Selatan. Gramatika: Jurnal Ilmiah Kebahasaan Dan Kesastraan, 2(1), 3950.

https://doi.org/10.31813/gramatika/2.1.20 14.79.39--50

Badudu, J. S. (1995). Inilah Bahasa Indonesia yang Baik dan benar IV. Jakarta: PT Gramedia Pustaka Utama.

Bratawidjaja, T. W. (1988). Surat Bisnis Modern. Jakarta: PT Pustaka Binaman Pressind.

Direktorat Jenderal Peraturan Perundangundangan, Kementerian Hukum dan HAM. dan RI (2015). Pedoman Umum Ejaan Bahasa Indonesia.

Harari, Y. N. (2019). Sapiens: Sejarah Singkat Umat Manusia. Primanda, A (Ed.) Cetakan Ketujuh. Jakarta : Kepustakaan Populer Gramedia

Pemerintah Indonesia. (2009). UndangUndang Republik Indonesia Rebublik Indonesia Nomor 24 Tahun 2009 tentang Bendera, Bahasa, dan Lambang Negara serta Lagu Kebangsaan.

J.S. Badudu. (1993). Inilah Bahasa Indonesia yang Baik dan Benar II. Jakarta: PT Gramedia Pustaka Utama.

Kepala Arsip Nasional Republik Indonesia. (2014). Peraturan Kepala Arsip Nasional Repbublik Indonesia Nomor 2 Tahun 2014 tentang Pedoman Tata Naskah 
Dinas.

Mahsun. (2006). Metode Penelitian

Bahasa :Tahapan Strategi, Metode, dan Tekniknya. Jakarta: PT RajaGrafindo

Persada.

Mutiadi, dkk. (2018). "Ketidakefektifan

Kalimat Pada Surat Dinas Tingkat Desa

Se-Kecamatan Darma Kabupaten

Kuningan Dan Ancangan Pola

Pembinaannya." FON : Jurnal

Pendidikan Bahasa Dan Sastra

Indonesia, 13(2), 183-189.

https://doi.org/10.25134/fjpbsi.v13i2.155

2

Poerwadarminta, W. J. S. (1985). Kamus

Umum Bahasa Indonesia. Jakarta: PN

Balai Pustaka.

Putrayasa, I. B. (2014). Kalimat Efektif

(Keempat). Bandung: PT Refika

Aditama.

Ramadhanti, D. (2015). Penggunaan Kalimat

Efektif dalam Karya Ilmiah Siswa:

Aplikasi Semantik Studi Kasus Siswa

Kelas Xi Smk Negeri 2 Lembah

Gumanti. Gramatika STKIP PGRI

Sumatera Barat, 1(2), 167-173.

https://doi.org/10.22202/jg.2015.v1i2.123

6

Sugono, D. (2009). Mahir Bebahasa Indonesia dengan Benar (I). Jakarta: Gramedia Pustaka Utama.

Whorf, B. L. (1964). Language, Thought, and Reality: Selected Writings of Benjamin Lee Whorf. In J. B. Carroll (Ed.), Language. 